
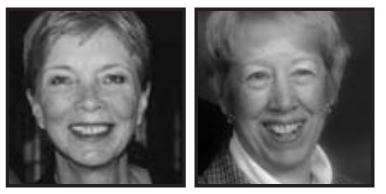

\title{
Engaging Students: The Power of the Personal
}

\author{
Lesley Pasquin \& Susan Winn, McGill University
}

\section{ABSTRACT}

Good teaching occurs when students can be themselves, can learn through application and collaboration, and can enjoy the excitement of discovery. That being the case, teachers today must compete with a society where students experience gratification and entertainment at the flick of a switch. The Internet and related technologies have changed the way that children learn and our understanding of the learning process. To address these changes, new teachers are entering schools with tools, expertise, and expectations that differ dramatically from past generations of pedagogues. Yet, in spite of the newly emerging views on learning, student engagement remains essential. The article shows that making curriculum personal for all learners is a basic premise of engagement.

e, the authors of this article, are two school principals returning to the university classroom to do what we love best: to teach. As members of the International Learning Community (a partnership between McGill University, school administrators and school districts in several countries), we were given the opportunity to witness both commonalities and differences in schools in England, in the United States and in neighboring Canadian provinces. The visits had afforded us with insights into how children learn and how they adapt to different classroom environments and widely contrasting curricula. As well-experienced educators, we have witnessed change in society and the impact this change has on the youth committed to our care. Many students reflect the effects of a fragmented family, non-conformist life attitudes, and abbreviated childhoods. As principals, we worked with teachers who were challenged to provide relevant learning experiences 
that prepare students for life in a complex world where knowledge changes exponentially. We were confident that, by using the strategies we had known instinctively throughout our careers in education, we could succeed in engaging students at every level. However, we acknowledged that our students might be motivated in different ways from those we had taught years ago. We found ourselves asking: What would be required to engage the learner of today?

When students are engaged in their learning, the magic of discovery is tangible, visible, shared and motivational, even for the observer. Engagement is a rapport: a space in which conversation occurs. It propels teachers to think about who they are and what they are doing. It asks them to reflect upon the following questions: Is our way of being enthusiastic, clear, passionate, and open? Are we providing situations for students that invite them in: elements of trust, relevance, and choice? Do we stimulate curiosity and build on strength?

Mihaly Csikszentmihalyi refers to engagement as, "... a connection between something inside and an opportunity outside to ...produce something real" (in Scherer, 2002, p. 7). Almost, all natural learning is constructivist, it seeks to find personal meaning in response to the world. Therefore, instruction must relate to what the student finds important to learn.

The Quebec Education Program is based on the tenet that learners construct their knowledge and their own world-view. Critical reflection, actions and reactions must be part of the learning process. The school curriculum can exercise a "decisive influence on the way students choose to construct, alter and develop their world view" (Ministry of Education of Quebec, 2001, p. 6).

The Web site Wordreference.com defines engagement as "human action; human activity; participation, involvement, involution and commitment: a dedication to bringing about change through the action of enfolding something; embracing and creating new knowledge through action, thereby constructing meaning." What a definition for engaging classroom teaching! 


\section{Lessons that Enfold: Embracing and Creating New Knowledge}

The issue of engagement is of paramount importance in our university classroom work. For the last 2 years, since leaving as principals of elementary schools of our own and having had 3 decades of involvement in classrooms, we have been teaching undergraduate and graduate level courses in the Faculty of Education at McGill University. We plan the lessons for our student teachers by taking into consideration their needs as well as our own. To engage them would certainly mean integrating technology into the sessions. We realize that we are sharing learning with students who are accustomed to working cooperatively and who are well versed in using laptop computers in the classroom and accessing information for assignments downloaded from the Internet. But it also means returning to the philosophy of experts such as William Glasser (personal communication, 1986) who asks educators to build a good "LAFF" into each lesson, that is, love (belonging), achievement, freedom and fun. In a similar vein, Richard Sagor (1993) coins an acronym he refers to as "CBUPO": the need to feel competent, to belong, and to feel useful, potent and optimistic.

In keeping with these thoughts, we aim to provide students in both our under-graduate and graduate classrooms with the opportunity to work cooperatively, to build the social structure of community, and, as much as possible, to have freedom of choice. To achieve this goal, we are prepared to respond to their efforts with words of praise and encouragement: "We care. You are valuable to us. Your learning is important." We know we need to create lessons that answer their questions, recognizing that through connecting to what they care about we can be engaging them in their learning.

Some students in our Assessment and Evaluation course, an undergraduate course in the Bachelor of Education Program, arrived with an urgent inquiry: How will I know that my students have learned? We were confronted in that question with the first requirement of engagement: connecting the curriculum to the great existential issue of success and failure (Ministry of Education of Quebec, 2001). To find the answer, we asked them to reflect on a skill they could do well, and to tell us why they knew they were good at it. Their answers ranged from "I know how to do it" (ability); "I am passionate about it" (engagement); "I am always learning to do it better," (evolution); to "Others ask me to show them, or I can teach someone about it" (transfer of knowledge). Through this inquiry process, we developed a rubric that students could use to evaluate their own learning as well as the learning of others. 
Some students in our Language Arts class, another course that is part of the Bachelor of Education Program, also arrived with an urgent inquiry: How do I teach children to read and to write? Our task was to find a way for our students to understand how their students would master these skills. We drew them in with two questions: What do readers do? What do writers need? These questions generated inventories that the students created and led the class into conversations about literacy by modeling what both readers and writers do. We created the space for them to become readers and writers themselves. They wrote their thoughts and reflections in their journals. Questions led to more questions. They pursued probable answers. They were motivated to create lessons based on real-life questions they might pose for their students, and perhaps more importantly, as well as those that their students might ask.

Freedom and creativity, we learned, are essential to engagement. To further their knowledge and make it practical and meaningful, students were asked to imagine the ideal Language Arts classroom. In this assignment, they were required to demonstrate how to provide a balanced literacy program in an enriched environment. The detailed models and drawings they presented were proof that they were well on their way to thinking like teachers! They began to feel competent and ready to experience a classroom setting. We witnessed in them a growing enthusiasm and anticipation about implementing their ideas, beliefs and practices in real, live classrooms.

\section{Lessons From the Field:The Doing}

Our theories seemed to be working. How would they apply what they were learning in the field? Would our students take what we had modeled and taught into the classroom? We suggest that the following anecdotes about two of our student teachers affirm our position. (All student names in this article are pseudonyms.)

\section{Stephanie}

Stephanie, a fourth year student teacher, welcomed us with a smile into her grade five inner-city classroom. We entered her student-teaching classroom now in the role of supervisors. She was relaxed and excited as she was nervous about the lesson she had prepared. She told us that she had intervened in a fistfight on the previous day, and that one young man was suspended. With a twinkle in her eye she added, "This is quite a group! But I am enjoying them and am learning a lot." At that 
moment, the children, like a herd of elephants, ran up the stairs and into the classroom. They were out of breath after racing against each other from the playground. Stephanie stood quietly by her desk with a rain stick in her hand. A rain stick is a musical instrument, a hollow cactus stem filled with tiny pebbles. Stephanie had learned that upending the rain stick produced a sound reminiscent of falling rain. She held it up and the students grew quiet as she let it speak its gentle message. She had asked her students to tell her how she should ask for quiet, and they had chosen her rain stick. It was their choice, and they respected its meaning.

Stephanie's lesson involved reading an excerpt from a story she knew would catch their attention. The Face on the Milk Carton (Cooney, 1996) is a compelling story of a young girl, Janie, who discovers her own face, many years younger, on a milkcarton message about a missing child. What should she do? Who should she tell? Was it really her face on the carton? Was her family really her family?

Stephanie's skillful reading, her timing of pauses, and her energy behind the words built a feeling of suspense that was gripping. Stephanie stopped reading and asked the students to assume the role of someone who could help the girl in the story. She suggested to the students that they could ask her questions or give her advice as she played the role of the young girl. The rain stick was to be used as the signal to move into a character role, and out of it again. We found ourselves wondering breathlessly if these students could handle this challenge. Speaking from their seats in this tightly crowded classroom, some assumed accents and became guidance counselors, teachers, police investigators and friends of the girl. Their questions and comments were astounding, showing a real understanding of the dilemma at hand. It was like watching a magical performance. We lost track of our supervisory role and entered the world of the narrative drama.

Later we reflected on this hour-long lesson and realized we were watching a young teacher who had the natural instincts to make learning fun and inclusive. Her rapport with her class indicated mutual respect and caring. The students were free to choose their roles and to respond to a teacher who included them in classroom management decisions. When students are invited to make choices about real and relevant topics in an environment of trust, encouragement and discovery, they learn.

\section{Nicole}

The students were chatting and moving into their desks when we slipped into the classroom to observe, Nicole, a third-year student teacher. These sixth graders 
had been trapped indoors during a rainy-day lunch period. "I had the strangest thing happen yesterday when I arrived home from school," Nicole began in a matter-of-fact way. She had the students' attention in no time. They wanted to hear what she was saying."I found this letter waiting for me." Nicole held up the envelope. The students sensed a mystery and wanted to hear every word. You could hear a pin drop. They craned their necks in anticipation. The young teacher had her students in the palm of her hand. They were "hooked." The lesson was underway.

The letter, we discovered later, had been written in the voice of one of the characters from the novel, Holes (Sachar, 1998) a story about a boy named Stanley Yelnats who chooses camp over jail for his sentence for a crime he did not commit. The students knew exactly who had written to their teacher from the clues in the letter. A discussion followed about the characteristics that made each individual in the story unique. The students were asked whether or not they had ever tried to stand in someone else's shoes. They reminded the teacher of their recent debate about the three little pigs versus the wolf. The class had held a court case with judge, lawyers, and jury. They had already learned much about empathy. They were challenged to work in groups to write a letter in the voice of one of the characters from the novel they were reading together.

Seven in the class of twenty-seven students had significant learning challenges, but not one was disengaged. Nicole is a teacher who models courtesy and sensitivity. Her students respect and appreciate her because she cares about each one. Her creativity and her caring are rewarded when all her students are passionately engaged.

During this particular session, Nicole demonstrated a willingness to give time to students who required personal assistance. Her lesson accommodated a diversity of expression and range of abilities. Group work enabled each student to use her or his individual skills and strengths.

\section{Lessons From our Graduate Students:The Being}

Our third group of students, who were participating in a graduate program in Educational Leadership at McGill, arrived with urgent inquiries as well! One question was: How can I be an effective and honorable leader and community builder? We responded to the question with another: What is a leader? Together we created our 
own definition. Their responses—"visionary," "fearless," "diplomatic," "serene in a sea of chaos," "empathetic," "flexible," "humorous," "generous," "knowledgeable," and "encouraging" - will remain with them far longer that any text could provide. Generating the list spurred on the social constructivist approach needed to build understanding.

When we prepared our course outline for this "Principalship" course, we asked ourselves: What would have engaged us if we had been offered a similar course in our beginning years as school administrators? We determined that practical help in dealing with difficult people, in developing and writing grant proposals, and in using ways to organize to multi-task, and developing techniques to maintain a worklife balance were some of the issues we could all share. We were very aware that the professionals in this course, principals, vice-principals, and a few aspiring leaders would have much to teach. Based on the topics on our course outline, the students brought us professional articles, copied for everyone, as well as letters on a wide range of topics written to their communities, and stories from their daily experiences both real and challenging. The communities in which these students were leaders represented a range of schools from the Youth sector (both elementary and secondary), as well as centres from the Adult and Vocational sectors. One student worked in a school dedicated to students with learning and physical difficulties. By developing an atmosphere of collegiality and trust we were able to tackle challenges that arise for both school and centre administrators. Together we found commonalities and differences, aware that our varied journeys in education require flexibility and openness to change. Above all, they require empathy for those we teach and lead: comfort, caring, freedom and fun.

If you have ever watched as a young child painted or built a tower of blocks, you will know that engagement lies in the creation of a personal project. University of Alberta professor Sylvia Chard (2001) defines a project as "an in-depth investigation of a real-world topic worthy of attention and effort." We witnessed the power of project in our graduate class. Students were asked to pick a real-school problem and brainstorm solutions in small groups. Topics included such themes as surviving recess and lunch, bridging the gap to high school for special-needs students, supporting new teachers, and getting tenured teachers on board. The interest was palpable, not only among the team members, but among the audience as well. Each project was worthy of presentation at a conference. Each student had answered a question that was real and important. 
Our graduate students gave us their best. From PowerPoint ${ }^{\circledR}$ presentations to modeled staff meetings, and newly developed brochures to personal learning journals, their commitment to ongoing learning rewarded our efforts to build a professional learning community. They were engaged in building this community and in collaboratively constructing new knowledge of visionary leadership.

Tom, one of our graduate students, is the Centre Director of a vocational school on the outskirts of Montreal. He is so proud of the students and staff in his centre. He invited us to his Open House. We had been so impressed with Tom's contributions to our class that we were certain a visit to his context would give us insights into motivation and engagement in adult learners. What we witnessed was a lesson in, and a definition of, engagement leading to excellence.

Our visit to Tom's centre exceeded our expectations. Many of the students in the centre had arrived laden with the baggage of failure, frustration and defeat. They were leaving as master craftsmen and craftswomen. We met students who were proud of their accomplishments, and teachers who were preparing to celebrate their students' successes. Cabinetmakers, landscape artists, nursing assistants, administrative assistants, home builders and homecare workers were demonstrating their skills and handiwork. Displays around the centre boasted the students' "portfolios" as Tom called them. The tour of this facility was a lesson in student engagement. We wished that every student could experience the joy of creating by being exposed to adequate tools and to expert guidance.

\section{Making a Space for Learning}

As educators, it is indeed our "being" and "doing" that engages students. It becomes our mandate to provide the kind of classrooms that invite learning to occur. We must provide classrooms where students, regardless of age or level, have freedom of choice; know their voices are heard; create their own knowledge under masterful guidance; feel they belong to a community; and, simply enjoy as they learn. Classrooms must be a place where teachers are challenging students to dream and to question. In such a place, the teacher says, "Together we will make sense of the world." This is learning. This is the power of the personal. 


\section{References}

Chard, S.C. (2001). Project approach: three phases. Retrieved in 2007 from http://www.pro ject-approach.com/development/phases .htm.

Cooney, C. (1996). The Face on the Milk Carton. New York, NY: Delacourt Press.

Ministère de l'Éducation (2001). Quebec Education Program: Preschool education and elementary education. Quebec, QC: Author.
Sachar, L. (1998). Holes. New York: Farrar, Straus and Giroux.

Sagor, R. (1993). At-risk students: Reaching and teaching them. Swampscott, MA:Watersun.

Scherer, M (2002). Do Students Care About Learning? A Conversation with Mihaly Csikszentmihalyi. Educational Leadership, 60(1), 34-38.

Wordreference.com. Retrieved in 2007 from http://wordreference.com

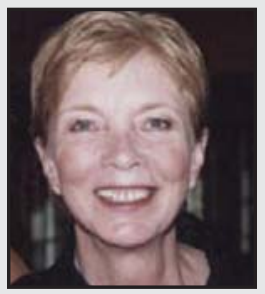

Lesley Pasquin is a writer, poet and educator. She has been a classroom teacher, a resource teacher, an Educational Consultant and an Elementary School Principal. She is currently an Adjunct Professor in the Department of Integrated Studies and the Centre for Educational Leadership in the Faculty of Education at McGill University.

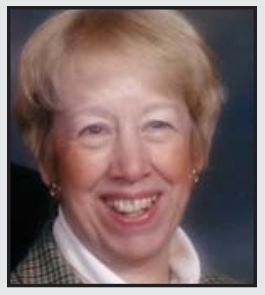

Susan Winn has enjoyed her career in Education as a classroom teacher, an Educational Consultant and as a School Principal, in both elementary and secondary schools. With three married children and seven grandchildren, Sue enjoys a wide variety of family, church and school-related activities. Currently Sue is an Adjunct Professor in the Department of Integrated Studies and the Centre for Educational Leadership in the Faculty of Education at McGill University. 